\title{
a voz do editor: uma conversa sobre pornografia e erotismo com ronnie cardoso
}

\section{Cleber Dungue e}

\section{Elisabete Ferraz Sanches *}

* Entrevistadores: Cleber Dungue é doutorando do Departamento de Teoria Literária e Literatura Comparada (FFLCH/USP) e bolsista CNPq. E-mail para contato: dungue@ usp.br. Elisabete Ferraz Sanches é editora da Revista Opiniães 6/7, doutoranda em Literatura Brasileira do Departamento de Letras Clássicas e Vernáculas (FFLCH/USP) e bolsista CNPq. E-mail para contato: efs@usp.br.
Pesquisador da pornografia e da estética da perversão na literatura brasileira, Ronnie Cardoso desenvolve sua pesquisa de doutorado em torno da obra do escritor Glauco Mattoso, orientado pela Prof. a Dr. a Eliane Robert Moraes. Como um dos editores desse número da Revista Opiniães, ele propôs o dossiê "Literatura e sexo: questões estéticas e/ou morais", com o objetivo de motivar e ampliar as discussões sobre os modos de representação do sexo na literatura. Das inúmeras questões discutidas pelos editores ao longo do processo de elaboração da Revista, veio a ideia de apresentar ao leitor alguns pontos da problemática que esta tópica literária 


\section{opiniães}

envolve. Para contribuir com os questionamentos sobre o assunto, convidamos o doutorando em Teoria Literária e Literatura Comparada, Cleber Dungue. Nesta entrevista, Ronnie Cardoso fala de erotismo, pornografia, perversão e muitas obscenidades literárias.

1) Quando o assunto é literatura e sexo, geralmente as palavras erotismo e pornografia aparecem como categorias distintas. Nesse sentido, pode-se demarcar claramente uma diferença entre elas ou seria meIhor pensá-las em uma relação complementar?

Alain Robbe-Grillet foi bem provocativo ao afirmar que a "pornografia é o erotismo dos outros". Há quem diga que o erotismo é algo velado, que transcende poeticamente o sexo, enquanto a pornografia seria uma exposição chocante, que provoca escândalo. A separação de ambas sempre me pareceu espúria ou mal colocada. Não as penso como categorias distintas de representação, já que um termo suplementa o outro semanticamente. Apesar das tentativas de alguns pesquisadores em distingui-las conceitualmente, a diferenciação não parece ser muito convincente, além de ser pouco operacional. Encontramos definições ancoradas em um cristalizado binarismo, estabelecidas pelo entendimento do senso comum ou mesmo limitadas pela compreensão de campos teóricos variados. Geralmente, a definição mais aceita estabelece a dicotomia entre sexo explícito, grosseiro e vulgar, que estaria presente na pornografia, e sexo implícito, nobre, galanteador, que faria parte do erotismo.

\section{2) Há uma discussão moral norteando a divisão en- tre pornografia e erotismo? E qual relação teria esses termos com os conceitos de obsceno, licencioso e lu- bricidade?}

Com certeza, há um valor mais moral que estético pau- dicotomia, quer seja entre obsceno e erotismo, quer entre pornografia e erotismo, insiste no equívoco de colocar a arte no alto, como elevação do espírito pelo belo, desvinculada, portanto, de uma estética que tratasse da matéria "do baixo material e corporal", que seria da ordem do popular e não da arte. Por não concordar com essas polarizações, parto da ideia de que o erotismo é o conceito, estabelecido a partir da experiência de dissolução, como pensa Bataille em sua célebre obra $O$ erotismo, que vai potencializar o valor literário da pornografia. Para este filósofo, o erotismo é essencialmente o campo da violência e da violação. Em sintonia com essa proposição, portanto, acho que devemos pensar a pornografia como um conceito dinâmico que articula todas as possibilidades da representação, que põe em cena $o$ ato sexual quando este se apresenta explicitamente ou, ainda que implícito, subtendido, mas que esteja em confronto com a moral vigente, com os interditos sociais e com o bom tom da linguagem oficial. Nessa perspectiva, o obsceno, o licencioso e o exercício lúbrico - este mais diretamente associado com o efeito de excitação sexual — são os mecanismos que fazem parte do sistema poético do qual a pornografia faz uso taticamente. Em minha pesquisa, procuro revitalizar e alargar a compreensão do que é pornográfico antes que o termo seja subutilizado para designar somente produtos da indústria cultural.

\section{3) No campo da literatura pornográfica, quais obras e autores mais atraem seu interesse de leitor e de pes- quisador?}

Dos inúmeros textos que podem ser considerados erótico-pornográficos, interesso-me por aqueles que apresentam alguma qualidade estética. Para perceber a qualidade literária de uma obra erótico-pornográfico, vale a pena ler toda a produção do Marques de Sade, principalmente Os 120 dias de Sodoma. Destaco ainda 
Três filhas da mãe, de Pierre Louÿs, As onze mil varas, de Guillaume Apollinaire e Um romance sentimental, de Alain Robbe-Grillet. No Brasil, os melhores exemplos do texto pornográfico com qualidade literária são: a trilogia obscena de Hilda Hilst (O caderno rosa de Lori Lamby, Contos d'escárnio: textos grotescos e Cartas de um sedutor), A fúria do corpo e Acenos e afagos, de João Gilberto Noll e Coxas, de Roberto Piva.

\section{4) Historicamente, poderia ser demarcado o momen- to em que a literatura erótico-pornográfica apareceu?}

Se buscarmos na tradição das letras ocidentais o que se convencionou chamar de literatura erótica, obscena ou pornográfica, encontraremos na Antiguidade as priapeias. Sob o gênero priapeia, reuniu-se um conjunto de poemas dedicados ou que remetem ao deus da fecundidade, Príapo, divindade que é representada com um membro genital de tamanho exagerado e em constante estado de ereção. Nesse contexto, a obscenidade pode ser relacionada com o culto reverente ao deus Príapo.

5) Ainda que na Antiguidade já existissem textos notórios da literatura erótico-pornográfica, quando ela se torna mais representativa?

Embora a representação do desejo, da sensualidade, do erotismo, do sexo e dos órgãos genitais possa ser encontrada em todos os tempos e lugares, a pornografia como prática artístico-literária, ou mesmo como objeto de pesquisa, acompanha a longa emergência da Modernidade no ocidente, vinculada aos principais momentos desse período. Especificamente, a palavra pornografia apareceu primeiro em 1769 no tratado de Restif de la Brettone. $O$ tratado escrito por ele visava à regulamentação da prostituição para torná-la uma prática racionalizada.
6) Um dos livros mais vendidos e comentados nos últimos tempos é, sem dúvida, Cinquenta tons de cinza, que se tornou, aos olhos do grande público, um ícone da literatura de temática sexual. É possível pensar esse livro como um representante da estética erótico -pornográfica?

Ele pode ser considerado um livro erótico-pornográfico, mas não encontro nele qualidade literária. Ao contrário dos autores citados acima, que potencializam a singularidade do discurso pornográfico e procuram reinventá-lo, a autora de Cinquenta tons de cinza só incorporou em sua obra o aspecto comercial e consumista do sexo, deixando de lado questões que envolveriam o valor artístico e literário do texto obsceno; não vai além de uma gramática erótica que atende a uma determinada demanda do público consumidor.

7) Ainda que se trate de uma obra de pouca qualidade literária, como você disse anteriormente, a que você atribuiria o fenômeno de vendas alcançado em tão pouco tempo?

A pornografia comercial intenta excitar o receptor ao qual se dirige com a superficialidade da sexualidade, com as ações e os objetos tornados óbvios pela sua gramática: nesse movimento regulador, a anatomia genital e o coito são esvaziados de erotismo, assim se domesticam corpos e mentes. No caso desse livro, vários fatores contribuíram para o recorde de vendagem. Entre eles, cabe lembrar como a autora soube explorar a dinâmica da internet. $O$ texto que se transformou em Fifty Shades iniciou-se em um fórum virtual (fanfiction. net), no qual James começou a escrever e compartilhar histórias picantes imaginadas para os personagens Bella e Edward da série "Crepúsculo". Segundo a autora, ela apimentou a relação do casal e criou situações em que eles se envolveriam com sadomasoquismo 


\section{opiniães}

soft. Ou seja, ela partiu de uma obra de sucesso comercial e testou no fórum os efeitos de histórias supostamente transgressoras. Além do fórum virtual ter servido como primeiro instrumento de divulgação, nele a autora foi percebendo o que atendia à expectativa do leitor. Em função disso, James fez o que pode ser considerado soft porn, isto é, uma pornografia domesticada, esvaziada eroticamente sem o potencial subversivo e incômodo que está associado à pornografia de qualidade. A meta da literatura comercial é tão somente agradar ao leitor e não incomodá-lo. Enfim, após incorporar algo já testado, que preliminarmente atendia à expectativa de um determinado tipo de leitor, o mercado editorial, na certeza do sucesso, investiu pesado para transformar a referida obra em fenômeno de venda.

8) Você poderia mencionar alguma obra brasileira erótico-pornográfica que também atendeu às demandas do mercado editorial e fez sucesso?

A pornografia que se encontrava na obra da escritora brasileira Adelaide Carraro também procurava atender às demandas do leitor da sua época. Era uma pornografia feita para o mercado. Seus livros tiveram grande sucesso comercial em plena ditadura. Curioso que epítetos como "escritora maldita" e "uma das escritoras mais censurada do país" impulsionavam ainda mais as vendas dos seus livros. A censura funcionava como estratégia de marketing para se vender mais livros da autora, que se tornou muito popular nas décadas de 1960 e 1970. Portanto, o sucesso comercial não tem a ver com a abertura dos novos tempos. Recentemente, Bruna Surfistinha transformou seu livro em grande sucesso comercial, virou até filme. Contudo, perceberemos que seu livro é bem retrógrado e conservador, se o confrontarmos com os textos pornográficos de Hilda ao analisar o sucesso de um livro no mercado editorial, podemos até partir para um debate sociológico que nos permita entender o fenômeno da vendagem recorde, mas isso pouco contribui para a discussão da qualidade estética da pornografia.

9) Histórias de sexo sempre mexeram com o imaginário dos leitores. No caso da literatura erótico-pornográfica, pode-se dizer que ela potencializa as fantasias de quem a lê?

Tenho rastreado em Manuais de Psiquiatria do século XIX como a literatura pode influenciar a fantasia erótica. Em Psychopathia sexualis, por exemplo, pacientes do médico Krafft-Ebing descrevem a excitação que lhes provocaram a leitura de livros como A cabana do paiTomás, Robinson Crusoé, As confissões de Rousseau e os textos do Marques de Sade e Sacher-Masoch. Um bom exemplo para se perceber a influência da literatura na fantasia é o livro Tu não te moves de ti, de Hilda Hilst. Vale lembrar o comentário feito por Rousseau sobre os textos que algumas damas de sua época liam com apenas uma das mãos, enquanto a outra mão era utilizada para se masturbar. Em suas palavras, a imaginação erótica era inflamada por "livros que se leem com uma só mão".

10) Pensando ainda no sucesso de Cinquenta tons de cinza entre o público feminino, poderíamos dizer que existe uma literatura erótico-pornográfica pensada exclusivamente para as mulheres?

Segundo o mercado editorial, sim, para as mulheres seriam produzidos os livros de ficção erótico-romântica, nesses livros se encontraria uma certa pornografia "corde-rosa", que supostamente atenderia ao gosto feminino. Mas em termos literários, não há essa distinção, o que há é pornografia com qualidade estética ou não. 
11) Para além da dimensão comercial, ao longo da história, seria possível identificar uma profícua produção erótico-pornográfica feita por mulheres ou com uma enunciação singularmente feminina? Há estudos que enfoquem esse aspecto?

A voz da mulher no erotismo vem desde a poesia de Safo. Contudo, a questão feminina na investigação de uma estética erótico-pornográfica é bastante controversa. Por um lado, há uma série de estudos críticos feministas que destacam o mal que a pornografia causa às mulheres, pois quase sempre reforça o aspecto ideológico segundo o qual estas são naturalmente feitas para o prazer do homem, como se estivessem sempre a serviço deles. Existe um consenso entre as feministas, principalmente entre as americanas, de que a pornografia promove a violência e a superioridade machista, subordinando o desejo da mulher ao do homem, transformando-a em mero objeto sexual. Em função disso, asseveram que "a pornografia é a teoria e o estupro, a prática".

Por outro lado, há escritoras como Anaïs Nin que enfatizam a diferença entre a experiência sexual feminina e a masculina, além de mostrar como essa diferença evidencia-se no texto obsceno. Contudo, longe de apontar para uma relação direta entre a pornografia e a violência sexual contra a mulher, como o fazem as feministas norte-americanas, a sua percepção está voltada para uma linguagem do sexo que ainda precisa ser inventada. Anaïs Nin pensava em uma erótica desenvolvida pela sensibilidade feminina para a qual a linguagem do homem seria inadequada. A escritora portuguesa Maria Gabriela Llansol dá bem a dimensão da delicadeza e complexidade que perpassa o erotismo feminino quando escreve este poema: "apertar uma criança / contra o coração que a ama / deve ser como / sentir o pênis retido pelos seios / da mulher que o ama; algo que poderá ter a frescura / inquieta do ar que se respira num primeiro caminho". Nesse mesmo texto, mostra-se plenamente em consonância com a percepção de Anaïs Nin ao concluir: "o texto refere-se ao real / como se tivesse a forma / de um rapaz; / mas, se a forma fosse outra, / a de uma rapariga, por exemplo, / pergunto-me ainda / se, no lugar cavo do seu sexo, / não deveria repousar, em permanência, / a mão direita de sua mãe". É certo que há uma delicadeza que perpassa o texto erótico feminino, entretanto o termo "feminino" diz aqui menos sobre uma diferença entre os gêneros (mulher / homem) e mais sobre uma performance do eu-textual na escrita. Em sintonia com a psicanálise lacaniana, compartilho a ideia de que a mulher seria a portadora privilegiada do feminino, mas não exclusiva. Há homens que também desenvolvem uma escrita feminina. No Brasil, a erótica literária tem se beneficiado dessa dicção feminina, bem apropriada ao decoro estético que persiste em nossas letras. Entretanto, salvo algumas exceções, os autores brasileiros mais significativos para cada época (incluindo aqui as escritoras), tanto sob o ponto de vista quantitativo quanto qualitativo, pouco exploraram a potencialidade da pornografia.

12) No Brasil, uma das escritoras mais populares da literatura erótico-pornográfica, como você já citou, foi Adelaide Carraro. Embora sua obra tenha sofrido com a censura imposta pela ditadura militar, seus livros foram um fenômeno de vendas. Dentro da tradição das mulheres escritoras, como você situaria a obra da autora?

Como disse antes, sua pornografia atendia às demandas do mercado da época e a censura impulsionava as vendas dos livros. A denúncia social e as questões políticas, quase sempre associadas ao ingrediente erótico e ao sentimentalismo, hoje nos parecem ingênuas e superficiais. Os personagens marginais retratados pela 
autora sucumbem, quase sempre, ao julgo moral da sociedade ou se redimem do caminho "degenerado" em que se encontravam, tendo em vista princípios supostamente nobres que reorientarão sua vida: por exemplo, em $O$ travesti, o protagonista sai de uma situação degradante ao receber uma herança deixada por seu empregador. O personagem que dá título ao romance abandona a prostituição, retira o silicone do corpo e abjura sua orientação sexual, por fim, torna-se pai exemplar e um marido dedicado. A escritora não propunha nenhuma subversão moral ou estética. Nada havia aí de criatividade. Comenta-se inclusive que ela dependia de algum ghost-writer para criar seu texto. Cassandra Rios dizia que lhe coube fazer a reescrita ou revisão de vários livros de Carraro.

13) Assim como Adelaide Carraro, Cassandra Rios também foi uma autora que teve grande aceitação do público. A popularidade da escritora, no entanto, não se restringia aos leitores da cultura de massa, sua literatura também chegou, de alguma forma, a figuras notórias como Jorge Amado, Érico Veríssimo, que defenderam seus livros da censura, e Maria Bethânia, que declarava seu entusiasmo pela obra da autora. No projeto de Cassandra Rios, além do universo lésbico e gay, também aparecem temas como adultério, assassinato e perversão. Isso faria dela uma escritora que rompe com os moldes tradicionais de representação adotados pela estética da pornografia comercial?

Em carta que escreveu para uma amiga, datada de 24 de junho de 1981, Caio Fernando Abreu, já bastante reconhecido por sua obra, disse que ficou "paralisado" quando encontrou aquela que ele considerava um "mito": Cassandra Rios. Ele assim a descreve: "nada de casacos de couro, pulseiras grossas ou correntes: traços muito bonitos, um nariz fino, uma testa ampla, uma voz "dizer nada além de um besta 'muito prazer'". Para muitas pessoas que viveram entre as décadas de 1950 e 1980, período de grande produção da autora, Cassandra Rios era realmente um "mito". Além de admiradores, há também muitos estudiosos da obra dela, como Rick J. Santos, professor da Universidade de Nova York. Em sua tese de doutorado, ressalta a importância da obra da autora para a formação de uma literatura gay e lésbica no Brasil. Entretanto, não deve nos passar despercebido que a escritora não vai além dos clichês do gênero. Em Eu sou lésbica, por exemplo, considerado um dos livros mais ousados de Cassandra Rios, as perguntas retóricas que encerram a narrativa parecem ser direcionadas a um leitor imaturo ou pouco exigente: "eu sou lésbica, deve a sociedade rejeitar-me? [...] Em que situação uma homossexual deve ser rejeitada, compreendida ou aceita? Quando engana o homem com as suas dissimulações ou quando enfrenta a sociedade abertamente, sem esconder o que é?". O sucesso da obra de Rios está justamente em atrelar personagens marginais ao relato obsceno e a mensagens edificantes.

14) Partindo da ideia de que os projetos literários de Adelaide Carraro e de Cassandra Rios não romperam com os modelos da pornografia comercial, qual o lugar que a obra dessas autoras ocuparia na tradição literária brasileira, ou ainda, qual contribuição foi trazida por elas?

As obras de Adelaide Carrara, Cassandra Rios, assim como as de Marcia Fagundes Varella, Luiz Fernando Lima de Miranda e Amadeu Filho, entre outros, têm valor histórico, valem pelo registro antropológico, por pautarem as demandas do corpo e da sexualidade, ainda que limitadas às demandas da cultura de massa, entretanto não se configuram como objetos de qualidade literária. Os livros desses escritores apresentam, em menor ou maior grau, os preconceitos e prazeres em um contexto 
histórico específico, cuja força castradora se efetivava tanto por meio da censura do regime ditatorial, como por meio do cerceamento da indústria cultural. Contudo, para além dos aspectos históricos e culturais, ou dos estudos de gênero e do homoerotismo no Brasil, pouca ou nenhuma contribuição estética esses autores trazem para a revitalização do gênero que os tornaram reconhecidos.

15) Diferentemente do que aconteceu com a obra de Cassandra Rios e Adelaide Carraro, cujos livros foram um fenômeno de vendas, a produção obscena de Hilda Hilst não teve grande aceitação do público quando foram lançados. Ainda que ela achasse que a experiência com a pornografia interessaria aos leitores, isso não aconteceu na magnitude esperada por ela. No início da entrevista, no entanto, quando listou os autores mais representativos da estética pornográfica, Hilda Hilst foi a única mulher citada. Para você, qual foi a importância dela na configuração da estética pornográfica brasileira?

A estratégia obscena e licenciosa faz parte da dinâmica de toda a obra em prosa de Hilda Hilst. Contudo, na trilogia pornográfica da escritora, a explicitude da cena sexual está mais óbvia. Lançada no início da década de 1990, podemos lê-la como o resultado, ou o fecho, do caminho literário que os livros de Hilst desde o início já propunham. Na época, foi divulgado pela mídia, em consonância com alguns críticos acadêmicos, que a trilogia da autora fracassou tanto na sua intenção pornográfica, quanto comercialmente. Segundo essa percepção, fracassava a pornografia como gramática de figuras obscenas e como exercício lúbrico, fracassava ainda o desejo da escritora em ter sua obra lida por um grande público, até mesmo porque não houve um investimento mercadológico por parte das editoras. Contudo, ao fracassar, o projeto literário de Hilda Hilst reanimou e atualizou toda uma discussão sobre o sentido e os efeitos da pornografia. Eliane Robert Moraes, referindo-se a uma citação em que Hilst se dizia "livre para fracassar", compreende que "'fracassar' significa, neste caso, a possibilidade de arriscar outras formas do dizer literário. Supõe liberdade - e também coragem - de excursionar por regiões ainda não devassadas pelo gênio criador do artista, correr o risco do desconhecido". Podemos, já passado alguns anos deste evento literário, pensar nessa outra maneira de se falar em fracasso da pornografia na trilogia hilstiana. É o rompimento com os procedimentos acomodados da narrativa obscena que veremos a partir do fracasso do projeto pornográfico da escritora. Até então, a produção pornográfica brasileira recente, com raras exceções (entre essas exceções, não podemos deixar de citar livros como $A$ fúria do corpo de João Gilberto Noll, Coxas de Roberto Piva e todo o projeto literário de Glauco Mattoso) havia se consolidado como uma gramática de procedimentos narrativos, estabelecida apenas com o que mais facilmente excitaria o leitor. O fracasso do projeto de Hilda Hilst nos permite revisitar a tradição pornográfica sob uma nova perspectiva.

16) Na sua opinião, quais procedimentos textuais contribuem para que uma cena de sexo na literatura tenha valor estético e não seja simplesmente a repetição de clichês.

A boa cena de sexo precisa romper com o horizonte de expectativa do leitor. Isso acontece quando se esquadrinha o lado obscuro da nossa sexualidade. No caso da literatura, a descrição da cena sexual se beneficia dos artifícios da linguagem, que permitem exceder a medida do real. Como exemplo, cito um trecho de uma sequência do livro Três filhas da mãe, de Pierre Louÿs, em que a filha engravida a própria mãe em meio a uma orgia: "durante esse tempo, o senhor me enrabou (ele estava 


\section{opiniães}

talvez tão bêbado quanto mamãe) e disse para mim, antes de gozar: 'faça um filho em sua mãe com seu cu, cague essa porra na buceta dela". O Marquês de Sade foi o grande mestre, inigualável, nessa arte de usar do excesso e da desmedida para descrever a cena erótica, rompendo com todas as leis, inclusive subvertendo a lógica da representação, além de incitar a imaginação do leitor. O escritor francês descreve, em Os 120 dias de Sodoma, a cena em que um homem "fode uma cabra de quatro enquanto a açoitam. Ele faz um filho nessa cabra, que ele enraba por sua vez, embora seja um monstro". No cinema, há também muitas cenas inquietantes do ponto de vista erótico. No filme "O império dos sentidos", por exemplo, tem uma sequência em que uma mulher introduz um ovo de galinha dentro da própria vagina a pedido do amante. $O$ que isso provoca na imaginação e no corpo do espectador? Com certeza provocará estranhamento. Enfim, penso que uma boa cena de sexo, mais do que excitar, deve inquietar o receptor e lhe colocar em estado de interrogação.

17) Se uma boa cena de sexo deve "romper com o horizonte de expectativa do leitor", na perspectiva inversa, quais seriam os dispositivos que reforçam a manutenção da norma e da gramática da sexualidade?

As cenas que não considero boas do ponto de vista artístico ou literário são aquelas que mostram apenas a superficialidade do sexo. Como consequência, a força erótica da representação é neutralizada: tudo já se sabe, tudo já se espera, haja vista a subserviência aos ditames da indústria cultural. A pornografia comercial subjuga o receptor com a gramática do sexo: nesse movimento regulador, a anatomia genital e o coito são esvaziados de erotismo, cujo campo de atuação está relacionado sobretudo às operações de violência e da violação, de supressão de limites, principalmente no plano estético. da imaginação e da representação do sexo. Ainda que haja cenas de sadomasoquismo, tudo ali é controlado: "há um contrato que especifica o que faremos e o que não faremos. Tenho que saber quais são seus limites, e você tem que saber quais são os meus", diz o dominador Christian Grey à neófita Anastasia Steele.

18) Em mais de uma resposta, você aponta para a ideia de que o valor da literatura pornográfica estaria na coragem de mostrar tudo sem pudores. Podemos dizer que os textos que operam por meio desse procedimento são decididamente obscenos?

O desnudamento é ação decisiva na obscenidade. É uma estratégia de comunicação que se opõe à ocultação. Alguns autores, entre eles Havellock Ellis e D. H. Lawrence, têm insistido numa proposição instigante de pensar o obsceno como algo "fora de cena". De certa forma, essa perspectiva se relaciona com a ideia de dar visibilidade por meio do texto artístico ou literário ao que, normalmente, por diversos mecanismos repressivos, permanece escondido. Lawrence chega a considerar que, como ninguém sabe definir com precisão o que significa "obsceno", deveríamos supor que derivou de obscena: aquilo que não pode representar-se no cenário. As palavras latinas obscenus, obscenae representam aquilo que conduz ao "mau augúrio", ou que o carrega. Ao longo do tempo, passou a denominar ain$\mathrm{da}$, na linguagem corrente, o aspecto frio ou horroroso de um objeto que se deve evitar ou esconder, porque se apresenta como impuro ou porque pode ferir o pudor. $\mathrm{O}$ ato obsceno configura-se, assim, como a perturbação ou violação da organização sagrada do corpo, pois transgride as proibições oculares e põe em cena nossas funções sexuais e excretoras. Nesse sentido, para não ficarmos apenas no plano da representação, o excesso torna-se um parâmetro necessário para ampliar as possibilidades estéticas de um texto obsceno. 
19) Você, como estudioso do erotismo/pornografia, propôs o dossiê "Literatura e sexo: questões estéticas e/ou morais" para esse número da Opiniães. Quais eram suas expectativas? A que conclusão você pôde chegar com essa edição da revista?

Até pouco tempo atrás, parecia-me que o decoro do meio intelectual brasileiro era um obstáculo aos estudos que envolvessem a dimensão estética do erotismo ou da pornografia. Certa vez, disse à profa. Eliane Robert Moraes, em um congresso da ABRALIC, que ela havia nos permitido ser pesquisadores menos envergonhados. Sem dúvida, ela foi a mais importante desbravadora dessa linha de pesquisa no Brasil. Os livros e artigos dela contribuíram para ampliar o repertório crítico em torno da erótica literária e influenciaram muitos estudiosos que investigam objetos estéticos relacionados com a obscenidade. Tenho percebido um aumento no número de estudos literários em torno desses temas que a academia costuma manter na marginalidade. A quantidade de artigos recebidos para o dossiê desse número da Revista Opiniães reforça esse entendimento. Surpreendeu-me sobretudo a variedade de enfoques em torno da relação entre sexo e literatura, além da diversidade dos textos analisados, indo da obra Gregório de Mattos ao livro publicado por João Gilberto Noll em 2012. 